\title{
Podredumbres \\ El parásito como un átomo de relación en filosofía, literatura y medicina
}

\author{
On the putrid \\ The parasite as "atom of relation" in philosophy, \\ literature and medicine
}

\author{
Hilderman Cardona-Rodas ${ }^{1}$
}

\section{Resumen}

Nietzsche, Pasteur y Zola hacen de la fuerza de la fermentación una de las condiciones de posibilidad de sus modalidades discursivas, vinculando al cuerpo que se corrompe, en descomposición, en tanto efectos sonoros en tres compuestos de sensación teórica. El operador de cambio, el equivalente general o átomo de relación: el parásito está presente en estos autores, asociado a la transvaloración de la profundidad en el plano filosófico, plano médico y plano literario, donde operan las fuerzas de la contaminación parasitaria del germen microbiano. Cuerpos degenerados, cuerpos corruptos, cuerpos descompuestos vistos en cada uno de estos planos que transmutan la idea de parásito puesto en escena por Nietzsche, Pasteur y Zola al construir cada uno de ellos tratados de parasitología: universos discursivos purulentos, donde demostrar es implicar, derivando en un desarrollo, en una explicación autorreferencial de desplazamientos de sentido en estos planos de lenguaje, derivados por este átomo de relación.

Palabras clave: Parásito. Bacteriologia. Nietzsche. Pasteur. Zola.

\begin{abstract}
Nietzsche, Pasteur and Zola make the process of fermentation one of the conditions of possibility of their discursive modalities, linking to the rotten body that breaks down and decomposes, in many sound effects in three compounds of theoretical sensation. The agent of exchange, the general equivalent or atom of relation: the parasite is in these authors, associated with the transvaluation of the depth in the philosophical, medical and literary levels, where the parasitical contamination forces of the microbial germ operate. Degenerate bodies, corrupted bodies, decomposed bodies are founded in each one of these levels, transmutating

\footnotetext{
${ }^{1}$ Doctorando de la Universitat Rovira i Virgili de Tarragona-España (cotutoria con la Pontificia Universidad Javeriana de Bogota-Colombia). Profesor de Tiempo Completo e Investigador del Departamento de Ciencias Sociales y Humanas de la Universidad de Medellín. E-mail: hildermanc@hotmail.com.
}

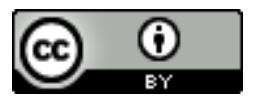

Esta obra foi licenciada com uma Licença Creative Commons - Atribuição 3.0 Não Adaptada. 
the idea of the parasite that Nietzsche, Pasteur and Zola bring through their respective construction of treaties on parasitology: putrid universal discourses, where to demonstrate is to implicate, leading to a development, to a self-referential explication of the displacement of meaning in these discourse of language derived from the atom of relation.

Key words: Parasite. Bacteriology. Nietzsche. Pasteur. Zola. 
Balada del disparatorio báquico, impregnada de múltiples romanticismos.

\section{- Dícela "el ebrio"}

Aquesto dixo "El Ebrio", una vegada.

Aquesto dixo con su voz cansada.

Aquesto dixo por la madrugada.

Yo dello non sé nada.

"Bebamos en las cráteras de oro que laboró el cincel benvenutino, champagne, bullente y bullicioso vino".

"Bebamos en las ánforas de barro

doria hidromiel; en el panzudo jarro

blonda cerveza, y en las cristalinas

frágiles copas el anís sonoro

así como las finas

mixturas sibilinas".

"Porque es dulce olvidar".

"Bebamos en las cráteras de oro

el líquido tesoro

que enloquece las mentes

y elide los deseos,

y que sume los sueños impotentes

en helados Leteos!".

"Porque es dulce olvidar. ¿Algo esculpido

quedar merece en el cerebro? Nada!

Porque es dulce olvidar..."

"El viento azota

la cima de los árboles, tedioso;

vacila el corazón ante la rota!

El espíritu vago!

¡La voluntad errátil

es un tortuoso Yago!

y el soñar aterido...:

¡el soñar aterido y nó vibrátil

ni altanero!... y nostálgico, anheloso

de una distinta vida...

"Los jardines románticos

horros están de idilios.

Y son hueros los cánticos

jocundos de Himeneo!"

"Dormita ya el Deseo!

Ya dormita el Amor!"

"Y yerra -enloquecida-

por sus lueñes exilios

de Dolor,

l'alma pura de Ofelia,

mientras Hamlet, moroso y taciturno

sepultóse en sí mismo!"

"Ya no existe

la verdad, si ha existido... Ya no es nada

la belleza, y lo es todo! y la tristeza

¡cómo es asaz vulgar y adocenada!"

"Yo bucéo un abismo

y el tal abismo es hueco!

Todo es superficial, mentido y triste.

Cad. de Pesq. Interdisc. em Ci-s. Hum-s., Florianópolis, v.14, n.104, p.85-105, jan/jun 2013 
Todo: el Amor y la Naturaleza,

el Mar, las Nubes, la ideal Belleza:

sólo restan cinismo,

rutina, y el enteco

sentido de lo práctico y la cómica

metafísica vómica!"

"Es preciso beber la sangre cálida

de los magos elixires!

Complicados brebajes, quinta-esencia, sudor de las retortas y alambiques;

todos los filtros químicos y alquímicos

el díctamo, el nepentes,

súmanme en la demencia!"

"En el absintio quiero que se esconda

-tras de sus de sirena glaucos ojos-

mi espíritu arbitrario,

mi corazón, y toda la amargura

de abolidos despojos!"

"Es preciso beber la sangre cálida,

sangre morena

o sangre blonda!

En el absintio quiero que se esconda

-tras de sus glaucos ojos de sirena

mi corazón, y toda la amargura!"

"La azul locura pálida,

soberana locura,

se asile en mi cerebro solitario!"

"Bebamos en las cráteras de oro

todo el licor que corre por la vena

de la pródiga uva;

y hagamos la serena

-la serena o la loca-

vida del que en sí propio no se toca

y que en nada se halla...:

-Búdico sér en éxtasis,

Jaiyám bajo los astros,

Edgar en la taberna,

Diógenes en su cuba...

Desdeñosos e impávidos,

sonrientes,

mirando la batalla

sempiterna, mirando la batalla

de apetitos, la gresca y el estridir de dientes

y el vulgar forcejeo

para ascender, para medrar, para vivir..."

"Nosotros -sí, nosotros-

olímpicos yazgamos sobre el trípode sacro:

claudicantes e irónicos,

sonrientes espectadores del simulacro,

sin recordar, sin añorar,

sin anhelar,

¡sin un solo deseo!"

"Bruña el trágico véspero

con sus hórridas lumbres

incendiarias;

dóre el amanecer con vagas lumbres

Cad. de Pesq. Interdisc. em Ci-s. Hum-s., Florianópolis, v.14, n.104, p.85-105, jan/jun 2013 
y medias-tintas de atediada suavidad;

o aljofáre la luna

del bebedor la cabellera bruna

o la blonda o endrina cabellera

nimbada de doliente claridad,

y bebamos el vino,

y bebamos el vino,

y bebamos el vino!"

Aquesto dixo el Ebrio una vegada.

Aquesto dixo con su voz cansada.

Aquesto dixo por la madrugada.

Yo dello non me curo. Yo dello non sé nada.

León de Greif 


\section{Primer movimiento}

Un cuerpo purpúreo, entre cuatro senos de Afrodita, flamea en las negras y relucientes sombras de lo visible y de lo enunciable. Fragante perfume. Felina boca. Soldados y frailes, ángeles y demonios, mujer y hombre. Este es el cráter de oro, cráter de madrugada y de atardecer, bullicio del vino, androginia de las bivalencias, donde la región del ánfora cristalina de idílicos filtros químicos y alquimísticos (región de superficies enigmáticas, caverna y montaña en concomitancia, donde habitan los efectos sonoros, los efectos ópticos y los efectos de lenguaje: efectos de superficie nietzscheanos de lo alto y de lo profundo, la transvaloración de la profundidad) de fermentación y de corrupción, por donde circula "el líquido tesoro que enloquece las mentes y elide los deseos".

Las fuerzas orgánicas, femeninas o masculinas, secas o húmedas, calientes o frías, naturales o culturales son producciones del cerebro-mundo del hombre. Los procesos de transformación de la materia vehiculan el trabajo humano, aparato de trasmutación que recodifica los objetos de la naturaleza en otros objetos naturales, brebajes, sudores, alambiques, filtros, percolaciones, metafísicas vómicas, mohos: perdidos, olvidados, sepultados por la Naturaleza póstuma, cerebro mezclado que ya no acepta la selva primitiva: "la naturaleza se ha perdido. Ahora bien, henos aquí ante un alto monumento de selva primitiva, un viviente en bruto. Esta brutalidad corta la respiración. $Y$ es el miedo. Lo sagrado no es sino la naturaleza pura" (SERRES, 1983, p. 41-42), un mundo sin hombres, testigos de la tierra bruta, mundo sin trabajo, universo abandonado donde no se bebía la sangre cálida, el vino de la insaciedad fetichista, la sangre morena, la sangre de ídolo y el epónimo de lo sagrado. La cultura permuta, mezcla, es mutante, modela y con ello olvida el forcejeo del primer cerebro solitario, ante la locura pálida e incandescente del éxtasis, de los astros, los apetitos y sus dientes de deseo de madrugada. Primera trasmutación es espiral de la boca felina de la primera fundación: la Imagen del mundo a través del aire cálido y lúgubre, los hielos permanentes y de miel sonora, de lo sagrado en el que se imprime el simulacro de la primera tumba y del primer perfume ebrio de la trasmutación. El espacio pagano, suma de las prácticas locales, se constituye por la combinatoria de piezas de un cuerpo de divinidades rústicas, lugar de la memoria donde el politeísmo o el paganismo despliegan la piel del elemento local antes del nacimiento del verbo. El vestido de Arlequín nos sirve para

Cad. de Pesq. Interdisc. em Ci-s. Hum-s., Florianópolis, v.14, n.104, p.85-105, jan/jun 2013 
comprender este plano proyectivo del estar ahí habitando los lugares propios de los seres dotados de vida. "El lenguaje y el monoteísmo vuelven homogéneo el andrajo pagano, la técnica pasa sobre los altares: destrucción de los viejos dioses vecinales, abolición del feudo y de los límites. El empirismo respeta y hace vivir cien divinidades locales, adorará incluso la del verbo. El monoteísmo hace posible la intervención técnica global: para formar un espacio isótropo fue necesario primero matar a los ídolos" (SERRES, 2002, p. 316).

Se trata de la conversión del rostro de lo divino, de lo sagrado, de la risa y de la voz del Creador. El Ebrio pasa, absorbe el vino, esconde su cabellera doliente y le asalta una nueva amargura, nuevos despojos, aparece la azul locura, el licor que horada la tranquilidad sonora: emerge la inversión de lo bajo en lo alto, del amo al esclavo. Dice Michel Serres: "el esclavo debe ser amo", que comprende el nuevo ritmo de las sombras, su propia sombra que se disuelve, se pudre, se transmuta en ebriedad ponzoñosa del andrógino en la inversión de la balanza, en turbulencias dadoras de significaciones, de brumas humanas que cantan el signo de sus sombras, de proporciones del espacio al que pertenece su cuerpo. La visión de un espacio medible que rodea "la nietzscheana visión futuradora; la búdica quietud..., y la pelea; y la Vida..., y la Muerte que me hiere sin desdén, sin amor y sin ira!"2, espectáculo de muerte y de vida, de verdad y de mentira que brillan, ambos, en la constelación de una esfera, donde lo uno puede ser lo otro. Transubstanciado de la cultura. ¿Lo visible transubstanciado es el espacio sonoro del amor y del odio? ¿Lo enunciable es expulsado por bocas flameantes del sol, por los rayos pétreos en el estado gaseoso en el discurso del pensamiento del afuera? Es posible afirmar que la historia de las relaciones de lo uno con lo múltiple en los niveles y estratos posibles de formalización hacen parte de cualquier práctica humana. Traspaso de señales e imágenes que pueden ser analizadas como mito, como leyenda, como tragedia, como fábula o como historia; todo un circuito empujado por signos y sentidos presentados como huella, escritura o geometral del mito a la historia y hasta de la historia al mito. La historia se pliega en múltiples facetas, múltiples movimientos, múltiples análisis, se bifurca en mito y en razón, en fábula y novela. La historia se noveliza, se estructura a partir de los elementos narrativos de orden mitológico. Es

\footnotetext{
${ }^{2}$ León de Greiff. Segunda "Balada del Abominario" para reír de aprestigiadas cosas y entidades o aprestigiar otras, Risibles según "Ellos".
} 
un juego de origen algebraico, combinatorio, provisto operaciones y relaciones con características definidas u ocultas en las huellas y en los gritos, en la caja negra. Es así como para Georges Dumezil (1984) la historia es una multiplicidad, una totalidad efectuante, plegada y puesta en funcionamiento en órdenes económicos o escriturarios, "digamos que es la totalidad concebida en el tiempo, de lo que un grupo, un grupo de grupos humanos o, en último extremo, el género humano cree saber de los acontecimientos de un pasado material y moral, desde los primeros esbozos hasta los balances más recientes" (DUMEZIL, 1984, p. 59). Primer movimiento fabricante del tejido de la Vida y de la Muerte en la configuración del tiempo humano.

\section{Segundo movimiento}

Nietzsche y El Anticristo son el bisturí en el templo, en el espacio cerrado, en lo sagrado descompuesto, cuerpo corrupto que llamea como debilidad por la enfermedad infecciosa del cristianismo, bestia doméstica, enfermedad de la bestia humana. El Anticristo es un evangelio que gira en torno al vicio de la corrupción de la interpretación de la historia del Cristianismo, decantación que ha generado una mirada falsa y parasitaria del "primitivo simbolismo". El Cristianismo nació y murió con el primer cristiano, y la intermitencia del "primitivo simbolismo" solo fue producto de la gradual descomposición de la fe, de la razón enferma ${ }^{3}$. Por ello, El Anticristo es un compendio de parasitología, donde Nietzsche propone la necesidad de lavar, expulsar, matar el bicho, el germen, por medio de una terapéutica que luche contra el bicho del cristianismo. Es la época de un nuevo suelo geológico ligada al pasteurianismo. "Utilizando un bisturí médico Nietzsche realiza allí la más depurada disección del cristianismo. El Intento es hacer una explicación de lo sagrado como peste que se propaga en términos bioquímicos" (GARAVITO, 1993, p. 99). Pero no solo es lo sagrado, sino que son los huesos mismos de la razón, sumida en la polución de la interpretación cristiana del mundo. Nietzsche descubre, por lo tanto, el paso de una "vieja alquimia o de una química desueta o un método más reciente. Lo

\footnotetext{
${ }^{3}$ Esta razón enferma que se descompone en ritos sangrientos de violencia religiosa es retratada por la película Ágora, dirigida por Alejandro Amenábar y estrenada en España el 9 de octubre de 2009. La película describe la vida de la filósofa y matemática neoplatónica griega Hipatia, quien fue asesinada en la antigua Alejandría (siglo $\mathrm{V} \mathrm{d}$. C) en el contexto del advenimiento del cristianismo, la declinación del paganismo y las luchas políticas entre los distintos sectores de la Iglesia. Hipatia murió en manos de una masa enardecida por el ideal ascético cristiano.
}

Cad. de Pesq. Interdisc. em Ci-s. Hum-s., Florianópolis, v.14, n.104, p.85-105, jan/jun 2013 
húmedo y lo seco son opuestos" (SERRES, 1994, p. 42). O lo que es lo mismo, el paso de una química de los elementos, una química de los opuestos, a una metafísica, stricto sensu. Tal paso se hace visible en el discurso químico, en lo referente a la conceptualización de lo sólido y de lo líquido, de lo líquido y de lo gaseoso vistos, no como contrarios sino a partir del punto de vista popular o por un entendimiento meta-físico. Tales estados emergen en el discurso nietzscheano en el salto de una base material "a un perfume exquisito: una transmutación de forma, de fragancia, de color" (SERRES, 1994, p. 42), mediante el paso por estos estados de la materia. Es una química que transmuta los colores, los estados, los olores, vaciados "en una química de la representaciones y de los sentimientos morales, religiosos, psicológicos e intersubjetivos" (SERRES, 1994, p. 43). En efecto, no se trata solamente de una cuestión religiosa, sino de toda una química de las representaciones y de los sentimientos.

Esta nueva química anuncia y constata la muerte de Dios, el fin de la teología, la muerte de la esencia, el fin de la metafísica y prueba de esta ruina la constituye el cristianismo. Éste "ha desterrado a todos los instintos fundamentales... de estos instintos extrajo y destiló el mal el hombre malo: considero al hombre fuerte como lo típicamente reprobable, como el 'réprobo"' (NIETZCHE, 1967, p. 461). Perversión humana de la virtud y de lo divino, transformación por una química de los opuestos que mata las coseidades ${ }^{4}$ naturales, muerte del hombre por el veneno y por el parásito de la verdad eterna.

Comte y Nietzsche, Pasteur en medio de los dos como intermitente discursivo, buscan la piedra como sólido y lo volátil como gaseoso, estado positivo y estado teológico.

\footnotetext{
${ }^{4}$ Para Martín Heidegger hablar de coseidad es detenerse en el ser-cosa, captar el carácter de cosas que poseen las cosas que son vistas como tales. Así, Heidegger elije el cuadro de Van Gogh de las botas desgastadas de un campesino. Este cuadro muestra el ser-cosa de las botas, es decir, su utilidad, unas botas que retratan el trabajo del campesino, su carácter de utensilio que lleva grabada la fatiga de la labranza, botas que exhiben el mundo de la vida humana. Cf.: Heidegger, 1996.
}

Cad. de Pesq. Interdisc. em Ci-s. Hum-s., Florianópolis, v.14, n.104, p.85-105, jan/jun 2013 
El estado teológico es nebuloso como un gas; el estado positivo es considerado como un sólido. Comte buscó la piedra, lo duro y expulsó la descomposición. Nietzsche se apunta también a la piedra, contra la arena y el polvo. Edad positiva, edad de piedra, desconfiada de sublimaciones, al corriente de donde ellas vaporizan. El odio por el gas exhalado, por los vapores impuros (SERRES, 1994, p. 44).

Este fenómeno parasitario lo describe Nietzsche como el animal doméstico, el animal del rebaño. Es el hombre enfermo, es el cristianismo, donde todos los sólidos se convierten en podredumbres de experiencias ascéticas cristianas. He aquí la epidemia, la peste, difuminada por los teólogos:

\footnotetext{
Yo declaro la guerra a este instinto de teólogos -el sacerdote visto como superior al hombre, por ser representante de la verdad, dice Nietzsche- en todas partes encontramos sus huellas. El que tiene en su cuerpo sangre de teólogo, tiene "a priori" una posición oblicua y deshonesta frente a las cosas. El "pathos" que de aquel se desarrolla se llama fe: que es un cerrar los ojos ante sí una vez para siempre, para no sufrir el aspecto de una insanable falsedad (NIETZCHE, 1967, p. 463).
}

Es la red infecciosa que pulula y contagia al hombre en una insanable falsedad de sí mismo. El germen de la moral, de la virtud, de la santidad que confunde la "buena conciencia con una falsa visión", afirma Nietzsche. Un pretender decir la verdad que infesta al hombre de virtud, espectáculo degenerado que fusiona política y religión, en un solo movimiento de virulencia hermética y del resentimiento monoteísta. Así, para Voltaire, "cada cual marcha alegremente hacia el crimen bajo la bandera de su santo". 5

Dios es el dios de los enfermos de virtud y de la moralidad, es una araña con su telaraña de eficacia social, es un "espíritu" de lo más corrompido posible. La idea de Dios, virus virulante de la sociedad, es "una hostilidad declarada a la vida, a la Naturaleza, a la voluntad de vivir, en el concepto de Dios" (NIETZCHE, 1967, p. 468). Hostilidad declarada, engendrada por la historia de un error, la muerte en la cruz, error "grosero", caldo de cultivo de virosis sociales, de un simbolismo "originario", el cual extendió razones e imaginaciones enfermas, "barbaries" enfermizas de la negación del otro. Al negar la vida y la naturaleza, el cristianismo traslada el centro de gravedad de la vida a la no-vida, según Nietzsche, en el más allá, en el limbo, en la nada, en el vacío; con ello, emerge la "inmortalidad personal" que destruye toda razón y toda "naturaleza en el instinto". Ante todo, la idea de Dios siembra la muerte, se puede convertir en el factor denominador de la razón asesina

\footnotetext{
${ }^{5}$ Citado por Gouteux (2006, p. 45).

Cad. de Pesq. Interdisc. em Ci-s. Hum-s., Florianópolis, v.14, n.104, p.85-105, jan/jun 2013
} 
que manda a matar en nombre de él. ${ }^{6}$ Él siembra la muerte: "ve, pues, y hiere a Amalec, y destruye todo lo que tiene, y no te apiades de él; mata hombres, mujeres, niños y aun los de pecho, vacas, ovejas, camellos y asnos." (Samuel, 15:3) He aquí una práctica genocida que busca destruir a un grupo mediante una masacre unilateral animada por una idea dogmática que deriva en fanatismo, comportamiento podrido de razón enferma. Según Cioran, "en sí misma, toda idea es neutra o debería serlo, pero el hombre la anima, proyecta en ella sus llamas y sus demencias; impura, transformada en creencia, se inserta en el tiempo, adopta figura de suceso: el paso de la lógica a la epilepsia se ha consumado... Así nacen las ideologías, las doctrinas y las farsas sangrientas” (CIORAN, 1949).

El "Dios", que inventa el san Pablo católico, "desacredita la sabiduría del mundo", preocupándose por desmentir a la filología y a la medicina, enemigos de toda superstición", extirpándola por medio de una ciencia de la higiene contra lo impuro-virulante. "En realidad no se es filólogo y médico con ser al mismo tiempo 'anticristiano'. Porque en calidad de filólogos se mira detrás de los libros santos, y en calidad de médicos se ve detrás del cristianismo típico de la generación psicológica. El médico dice: 'Incurable'; el filólogo dice: ‘charlatanería”' (NIETZCHE,

\footnotetext{
${ }^{6}$ Según José Saramago, "siempre tendremos que morir de algo, pero ya se ha perdido la cuenta de los seres humanos muertos de las peores maneras que los humanos han sido capaces de inventar. Una de ellas, la más criminal, la más absurda, la que más ofende la simple razón, es aquella que, desde el principio de los tiempos y de las civilizaciones manda a matar en nombre de Dios. Ya se ha dicho que las religiones todas ellas, sin excepción, nunca han servido para aproximar y congraciar a los hombres que, por el contrario, han sido y siguen siendo causa de sufrimientos inenarrables, de matanzas, de monstruosas violencias físicas y espirituales que constituyen uno de los más tenebrosos capítulos de la miserable historia humana" (SARAMAGO, 2011). Toda religión ofrece paraísos y amenaza con infiernos, imágenes que son insultos a la inteligencia humana. Siguiendo a Saramago, dice Nietzsche que si Dios no existiese todo estaría permitido, pero es precisamente por su existencia y en nombre de él que se ha permitido lo más horrendo de la historia humana que pacta una monstruosa relación entre religión y política y legitima asesinar en nombre de la verdad: el siglo $\mathrm{XX}$ atestigua matanzas, genocidios, campos de concentración, limpiezas étnicas e incontables fosas comunes haciendo visible el proyecto tanatopolítico contemporáneo (SERRES, 1974; ESPOSITO, 2006; MANN, 2009).

${ }^{7}$ Pablo de Tarso construye una idea de Jesús falsa y a partir de esta traición edifica la Iglesia Católica ligada al fanatismo religioso y a la ideología sangrienta. Pablo y su Iglesia promulga el odio al cuerpo, a las mujeres y a la vida. "Al comienzo, ese judío histérico e integrista gozaba persiguiendo a cristianos y asistiendo a sus castigos. Cuando los fanáticos lapidaron a Esteban, los acompañó. La conversión en el camino de Damasco, en el año 34, se relaciona puramente con la patología histérica: cae al suelo (y no de un caballo, como muestra Caravaggio y la tradición pictórica...), una luz intensa lo ciega, oye la voz de Jesús, no ve durante tres días y no come ni bebe durante ese tiempo. Recupera la vista después de la imposición de manos de Ananías, un cristiano enviado por Dios en missi dominici. A partir de entonces, se alimenta, se recupera y se lanza a los caminos durante años en su misión evangelizadora delirante por toda la cuenca mediterránea" (ONFRAY, 2006, p. 142-143). La misión evangelizadora deriva en una neurotización del mundo articulada por brutalidad ideológica, intolerancia intelectual, culto a la mala salud, odio al cuerpo del goce, desprecio hacia las mujeres, placer en el dolor de uno mismo y desprecio por la tierra en nombre de un más allá descompuesto de ideal.
}

Cad. de Pesq. Interdisc. em Ci-s. Hum-s., Florianópolis, v.14, n.104, p.85-105, jan/jun 2013 
1967, p. 460).

La limpieza. La asepsia. El temor a la descomposición y a la invasión del germen microbiano. Patología del aseo. El imperativo de una higiene que se enfrenta al deseo y ondea el odio al cuerpo. Respuesta terapéutica al aire puro y ascenso a la montaña, ascenso terapéutico que se ve en la obra de Thomas Mann La Montaña Mágica, montaña que destruye lo sólido de la corrupción por intermedio del "aire puro", transmutación de los valores para aniquilar al parásito que niega la vida y la naturaleza. Asimismo, en el Naná de Emile Zolá, una mujer se descompone ante un espejo, reflejando una sociedad puritana que se contamina ante el microbio; ante las moscas y el estiércol. El virus desagrega, produce lo podrido y corrompe: el hombre preso por la sangre fanática del teólogo. Es el gusano que ha disuelto el mármol. "Naná muere de virus, pero ella es el virus, cuya circulación imprevisible y ubicua descompone el cuerpo social. Gran animal hecho carroña por la puta virus, bello animal carroña por el virus de este virus. El mal corre, sucio y pequeño. Invisible, por todas partes" (SERRES, 1994, p. 45). La paranoia se generaliza, la psicosis por lo infinitamente pequeño, solo perceptible en el cuerpo social, en el orden del viviente, que trasmuta lo infinitamente grande, temor a los dioses, a los astros, al rey, a esta instancia por lo minúsculo que invade sacudiéndose en enfermedad fecundante, epidemia ante lo que no se ve, la purga del cuerpo infectado y su limpieza es lo que aboga Nietzsche en El Anticristo.

En esta dirección apunta la purificación del cristianismo. "El cristianismo tiene necesidad de la enfermedad, casi como la Grecia tenía necesidad de un exceso de salud; 'fabricar' enfermos es la verdadera intención recóndita de todo el sistema de salvación propia de la iglesia... (es la) 'locura circular'” (NIETZCHE, 1967, 493). Es una religión que enseñó a comprender el mal del cuerpo, el cuerpo cadavérico. Odio del cuerpo para encontrar la "perfección" y la "salvación" por medio del "alma perfecta". Ideal ascético de fanatismo ideológico animado por el concepto de Dios como antítesis de la vida, locura circular que va de la penitencia hasta las histerias de redención, dice Nietzsche en el Ecce Homo.

Esta enseñanza de la enfermedad, esta "locura circular", este virus virulante, este microbio circundante, este parásito que inunda e invade al hombre es una patología falsa, una enfermedad infecciosa que solo los débiles no perciben.

El "reino de los cielos" es un estado del corazón, no una cosa que adviene Cad. de Pesq. Interdisc. em Ci-s. Hum-s., Florianópolis, v.14, n.104, p.85-105, jan/jun 2013 
después de la muerte. Todo el concepto de la muerte natural falta en el Evangelio: la muerte no es un puente, un paso; falta porque es propia de un mundo completamente diverso, puramente aparente, útil solo para fabricar signos con que expresarnos. La "hora de la muerte" no es un concepto cristiano: la "hora", el tiempo, la vida física y sus crisis no existen para el maestro de la "buena nueva" [...] El "reino de Dios" no es cosa esperada: no tiene un ayer ni un mañana, no llegará dentro de "mil años", es una esperanza de un corazón, está en todas partes y en ninguna (NIETZCHE, 1967, p. 480).

De lo infinitamente grande a lo infinitamente pequeño, de los dioses del Olimpo, de los astros, de los planetas, de los meteoros, de las religiones politeístas a las religiones monoteístas, religiones enfermas de visiones de mundos-manicomios, en lo minúsculo, lo pequeño, lo no visible que se manifiesta por la emergencia de una farmacopea catártica de expulsión de la enfermedad, ¿será el traslado, la transmutación cultural de un macrodios o unos macrodioses infinitamente percibidos, a un microdios o a unos microdioses infinitamente ocultos? ¿Es un movimiento cataléptico en espiral de revolución de una religión que expurga al otro, considerándolo como peste productora de degradación, religión del miedo y de angustia a la corrupción, átomo-gusano y veneno, por ello perseguido y eliminado por medio de una propedéutica del cuerpo sano? Son sistemáticas, máquinas de guerra, dispositivos de filtración y de combate contra el microbio, contra el parásito, contra el fantasma de la corrupción.

\section{Tercer movimiento}

Las fuerzas de la transmutación, de la puesta en evidencia de un devenirenfermo, es el devenir-reactivo de todas las fuerzas.

\footnotetext{
El hombre activo (en oposición al hombre reactivo que practica las fuerzas liberadoras del pensamiento de la mala conciencia y del resentimiento, superando al hombre, destruyéndolo $y$, por tanto, mutando a un hombre que es la enfermedad de la piel de la tierra) es un hombre hermoso, joven y fuerte, pero sobre cuyo rostro se descifran los signos discretos de una enfermedad que todavía no tiene, de un contagio que solo le alcanzará mañana (DELEUZE, 1971, p. 235).
}

Este hombre propenso al contagio es el hombre del devenir-débil, en el que Nietzsche ve la inversión del mundo griego por el hombre teórico, Roma invertida por Judea, el Renacimiento invertido por la Reforma. Pero en el hombre se configuran fuerzas activas y fuerzas reactivas que lo teatralizan como sujeto enfermo 
y sujeto de voluntad de poder. Él vomita sentidos miméticos y sentidos reaccionarios.

Nietzsche o Lutero, dos cuerpos mezclados, un solo dolor lujuriante ante la polución por el virus circundante. Nietzsche ¿un nuevo Lutero? Lutero ante la iglesia-patológica. Su Reforma. La iglesia ante Lutero-contradictor. Su Contrarreforma. Nietzsche ante el parásito de olor fétido, ante el cuerpo social contaminado por la psicopatología de la ponzoña, el cristianismo y la sociedad puritana, veneno, suciedad, de las inmundicias que corrompen el granito del cuerpo primario, limpio de supersticiones. La sociedad puritana ante la putrefacción de su sangre, enfermedad líquida que corroe libremente el espíritu de los hombres. Su deseo de preservación del virus virulante para conservar el hambre de su saber enfermo, contagiado, que desvía del principio religioso por la interpretación de la religión primitiva.

Si la religión podría ser definida como "un sistema de símbolos que actúa para establecer vigorosos, penetrantes y duraderos estados de ánimo y motivaciones en los hombres, formulando concepciones de un orden general de existencia, y revistiendo estas concepciones con una aureolo de efectividad tal que los estados de ánimo y motivaciones aparezcan como un realismo único" (GEERTZ, 1987, p. 89), lo que deja entrever Nietzsche es precisamente la efectividad del virus virulante del cristianismo que penetra la conciencia de los hombres y mujeres generando estados de ánimo de realismo único envenenado de odio hacia la vida.

De esta forma, El Anticristo, en la propuesta de Nietzsche, es un Antecristo, una crítica contra el olvido de la religión primitiva. Nietzsche busca entre los escombros podridos de los orígenes, antes de Cristo, antes de Dionisios... Antecristo: antes de lo sagrado. "El Antecristo: el origen de lo sagrado antes del origen de la tragedia" (SERRES, 1994, p. 55). Pretende hallar la sopa primera de las culturas, el origen de la vida, el origen del saber de la vida, libre de "moralina".

Un pasaje de La serpiente emplumada de D. H. Lawrence, pone de manifiesto ese complejo de fuerzas profanas que se despliegan en el orden de lo sagrado, antes del nacimiento del verbo, antes de cualquier monoteísmo, que tanto buscó Nietzsche: 
noción de Dios está siempre alta y airada sobre nuestras cabezas. Los dioses mueren con los hombres que los han concebido, pero la noción de Dios permanece eternamente, rugiendo como el mar, cuyo sonido es demasiado vasto para ser captado. Rugiendo como el mar embravecido, que se estrella contra las rocas de hombres vivos y rígidos, a fin de destruirlos. O como el mar del centelleante y etéreo plasma del mundo, que baña los pies y las rodillas de los hombres como la savia de la tierra baña las raíces de los árboles. Hemos de nacer otra vez. Incluso los dioses han de nacer otra vez. Todos hemos de nacer otra vez (LAWRENCE, 1980, p. 64).

Para poder alcanzar este origen es necesario construir al hombre superior, el cual invierte los valores, convierte la acción en reacción. Transmutación de todos los valores, conversión de lo verdadero en falso, de lo falso en verdadero. La transmutación o transvaloración no es un

\begin{abstract}
cambio de valores, sino un cambio en el elemento del que deriva el valor de los valores. La apreciación en lugar de la depreciación, la afirmación como voluntad de poder, la voluntad como voluntad afirmativa. Mientas se permanece en el elemento de lo negativo es fácil cambiar los valores o incluso suprimirlos, es fácil matar a Dios; se conserva el lugar y el atributo, se conserva lo sagrado y lo divino, incluso si se deja el lugar vacío y el predicado sin atributo. Por cuanto se cambia el elemento, entonces, y solamente entonces, se puede decir que se han invertido todos los valores conocidos o cognoscibles hasta el momento (DELEUZE, 1971, p. 240).
\end{abstract}

De esta manera, desaparece la pretendida lectura de Nietzsche en cuanto ver en su pensamiento un nihilismo, éste desparece con el cambio del elemento, la recuperación del atributo, del derecho, con relación a instancias profundas del pensamiento en el que se deriva. En efecto, se trata de una crítica de los valores conocidos, no por medio de una práctica nihilista, sino a través de una trasmutación de la cultura. "La trasmutación seria, pues, un nihilismo acabado, porque facilitaría a la crítica de los valores una forma acabada, 'totalizadora'” (DELEUZE, 1971, p. 241). Los valores que caen en la crítica nietzscheana son todos los valores conocidos y cognoscibles, llevada a cabo por la voluntad de poder en general. "Lo que conocemos de la voluntad de poder es también dolor y suplicio, pero voluntad de poder sigue siendo la alegría desconocida, la felicidad desconocida, el dios desconocido" (DELEUZE, 1971, p. 242). Transmutación o transvaloración significa: a) cambio de cualidad en la voluntad de poder; b) paso de la ratio cognoscendi a la ratio essendi en la voluntad de poder; c) conversión del elemento de la voluntad de poder; d) reino de la afirmación en la voluntad de poder; e) crítica de los valores conocidos y f) inversión de la relación de fuerzas. Así, Deleuze ubica la real conversión: la percolación de lo negativo en afirmativo, trasmutando la cualidad y

Cad. de Pesq. Interdisc. em Ci-s. Hum-s., Florianópolis, v.14, n.104, p.85-105, jan/jun 2013 
descodificando el elemento.

Esta transmutación de los valores conocidos funciona en el caballete de la profundidad, que destituye, reasigna al elemento, abandonado la verticalidad y distribuyéndose por las regiones conocidas de la relatividad de los horizontes de verdad. Nietzsche es un saltimbanqui de la química de las sensaciones y de las representaciones, que busca en los cuerpos sólidos el agente patógeno de la degradación que yace en la profundidad mimética del espíritu humano. Pero el microbio es volátil, es aerobio, lo cual hace imposible la limpieza completa; la suciedad se propaga. El cristianismo expulsó las esporas de la mugre, enferma y envenena a la naturaleza y a la vida. "Mas la sangre es el peor testigo de la verdad: la sangre envenena incluso la doctrina más pura, convirtiéndola en delirio y en odio de los corazones" (NIETZCHE, 1967, p. 92).

\begin{abstract}
Yo "condeno" el cristianismo, yo elevo contra la iglesia cristiana la más terrible de todas las acusaciones que jamás lanzó un acusador. Para mí, es la más grande de todas las corrupciones imaginables, tuvo la voluntad de la última corrupción imaginable. La iglesia cristiana no dejo nada libre de su corrupción; de todo valor hizo un no valor, de toda verdad una mentira, de toda probidad una bajeza de alma [...] vive de miserias, creó miserias para eternizarse [...] Por ejemplo, el gusano del pecado: la iglesia fue precisamente la que enriqueció a la humanidad con esta miseria [...] El parasitismo como "única" práctica de la Iglesia; la Iglesia, que contra sus ideales enemigos, con sus idealidades de "santidad", chupa de la vida la sangre, todo el amor, toda esperanza; el "más alto" como voluntad de negar toda realidad [es una] conjura contra la salud [...] "contra la vida misma" (NIETZCHE, 1967, p. 504-505).
\end{abstract}

He aquí lo que llama Nietzsche la gran corrupción interior, la gran maldiciónque el cristianismo ha impreso en los hombres. Es necesaria la "transmutación de todos los valores" conocidos y cognoscibles, emergiendo, con ello, la destrucción activa entre las fuerzas reactivas y las transmutación de la voluntad de la nada, pasando al lado de la afirmación, poder de afirmar que destruye a las fuerzas reactivas.

La destrucción se hace activa en la medida en que lo negativo es transmutado, convertido en poder afirmativo. "Eterna alegría de devenir", que se declara en un instante, "alegría de aniquilación", "afirmación del aniquilamiento y de la destrucción". Este es el "punto decisivo" de la filosofía dionisiaca: el punto en que la negación expresa una afirmación de la vida, destruye las fuerzas reactivas y restaura la actividad en todos sus derechos. Lo negativo se convierte en el trueno y en el rayo de un poder de afirmar. En el hombre que quiere perecer, que quiere ser superado, la negación ha roto lo que aun la reteñiría, se ha vencido a sí misma, se ha convertido en poder de afirmar, ahora ya poder de lo sobrehumano, poder que anuncia y

Cad. de Pesq. Interdisc. em Ci-s. Hum-s., Florianópolis, v.14, n.104, p.85-105, jan/jun 2013 
prepara al superhombre (DELEUZE, 1971, p. 245).

Aparece la negación, sacrificadora de las fuerzas reactivas y destructoras de todos los caracteres degenerados y parasitarios.

Este cuerpo descompuesto, invadido, infectante, cuerpo degenerado sacudido por el mal que corroe, se encuentra asimismo en el cuerpo corrupto de Naná descrito por E. Zola, consumido por la viruela y escenario perfecto del primer estremecimiento: el contagio. "Pobre gata" desfigurada por el microbio circundante, parásito invisible que horada la carne como peste destructora.

\begin{abstract}
El cadáver -dice Zola- empezaba a despedir cierto tufo [...] El terror se apoderó de todas, después de tanta indiferencia.

-Volvamos, vamos gatitas- repetía Gagá. Esto no es sano.

[...] Una luz viva iluminó bruscamente la cara de la muerta. Fue horrible. Todas se estremecieron y huyeron.

-¡Oh!, está cambiada- murmuraba Rose Mignon, saliendo la última. Al salir cerró la puerta. Naná quedaba sola, la cara al aire, en la claridad de la bujía. Era un montón de huesos, lo que quedaba de humores y de sangre; una paletada de carne corrompida, arrojada allí sobre un colchón. Las pústulas habían invadido todo el rostro, un botón tocaba al otro, y marchitas, hundidas con un aspecto de barro gris, parecían un enmohecimiento de tierra sobre aquella papilla informe, en la que no había rasgos. Un ojo, izquierdo, estaba completamente sombrío en el hervor de la purulencia; el otro medio abierto, se hundía como un agujero negro y corrompido. La nariz supuraba todavía. Una costra rojiza partía la mejilla e invadía la boca, arrancándole una sonrisa abominable. Y sobre aquella máscara grotesca y horrible de la nada, los cabellos, aquellos hermosos cabellos, conservaban sus reflejos de sol, cayendo como un chorro de oro. Venus se descomponía. Parecía que el virus cogido por ella en los arroyos sobre la carroña tolerada, aquel germen con el cual había envenenado a un pueblo, acababa de subírsele al rostro y lo había podrido (ZOLA, 1982, p. 441-442).
\end{abstract}

Se comprueba entonces cómo en la segunda mitad del siglo XIX europeo la bacteriología se convierte en religión. El sentido desvelado, desplazado como estrategia teórica, de la limpieza, de la higiene, de la salud, de la corrupción, es comprendido, ahora, como expulsión, purificación, práctica de catarsis, vislumbrando en los tres planos discursivos escogidos en este texto: filosofía, medicina y literatura. El nuevo médico, el de la ciencia nueva, nos dice Serres, encuentra los gestos originarios de lo sagrado.

Persigue el mal, lo malo, al enfermo; lava el terreno con agua lustral, sube a
la montaña. Expulsa los portadores de virus, los responsables, los agentes
de la enfermedad y del mal, nuevos chivos expiatorios; recorta el templo, un
espacio cerrado, después de haber marcado el tiempo del eterno retorno. El
sable era un bisturí y de aquí que no es sino el bastón del sacerdote. El
combatiente se vuelve gemelo, mellizo de su enemigo. Hace los mismos
gestos, dice las mismas palabras, tiene los mismos argumentos, lleva la 
misma arma (SERRES, 1994, p. 41).

El discurso pasteuriano es parasitario, funciona como un virus virulante, efectivo. La bioquímica se construye en oposición al régimen discursivo reinante hasta ese momento: la heterogenia, comúnmente llamada generación espontánea, defensora de la idea de que el viviente era generado a partir de la materia inerte. Toda la batalla de la bioquímica, condición de posibilidad de la bacteriología, se dará sobre fenómenos como la descomposición, la putrefacción, la corrupción y la fermentación, es decir, fenómenos límite en el umbral de lo orgánico y de lo material, de la vida y de la muerte. Todos estos límites están en la escena de lo minúsculo, de lo invisible-visible. ¿Átomo o micro-organismo? Para Serres, en el siglo XIX se genera una controversia sobre el orden del viviente; por un lado, el naturalista FélixArchimède Pouchet y el historiador Jules Michelet apostaron por el átomo inerte, mientras que Louis Pasteur, partiendo de la diferencia de objetos casi sin diferencias: los cristales simétricos o antisimétricos, apostó por la existencia de organismos microscópicos, los microbios. De repente, todo el mundo se llenó de "pequeños animalitos nocivos. La ciencia de la higiene caía en una sociedad puritana y, de repente, la existencia exacta dibujaba lo impuro" (SERRES, 1994, p. 44).

\section{Conclusiones inconcluyentes}

En Nietzsche, Pasteur y Zola es posible encontrar tres modalidades discursivas que articulan sus enunciados a partir del concepto de parásito, el cual funciona como un operador de cambio, un equivalente general o un átomo de relación. Este concepto se asocia al fenómeno de la descomposición de la materia viva, de lo humano y de la tradición. Por ello, la urgencia de establecer terapéuticas liberadoras del elemento putrefacto, es decir, separar las manzanas sanas de las podridas, lo cual para el siglo XX derivaría en estrategias biopolíticas de control de la población vista como degenerada.

En esta medida, la Razón Pura es pura, limpia, aséptica, no corrupta; tiene las manos limpias, tiene la labor evangelizadora del decir verdad, razón asesina, razón tanatopolítica que fusiona moral y dogmatismo.

Ante la invasión del detalle, lo infinitamente pequeño, lo que no se ve pero 
sobre lo que se tiene "certeza" de que existe, lo menudo, de él deviene la epidemia y la putrefacción. La necrosis, la invasión fantasmática, el horror puritano, victoriano, de enunciarse, contaminarse las manos. Es así como a la pregunta ¿Quién manda en el mundo?, se responderá: el miedo, la angustia y la incertidumbre, en un contexto donde la infestación del fanatismo putrefacto gravita en el imaginario intolerante de las visiones de mundo de ideologías sangrientas.

El miedo a la muerte, en la historia de occidente, ha tomado tres figuras principales: primera, el hambre; segunda, el amor sexual; tercera, la enfermedad.

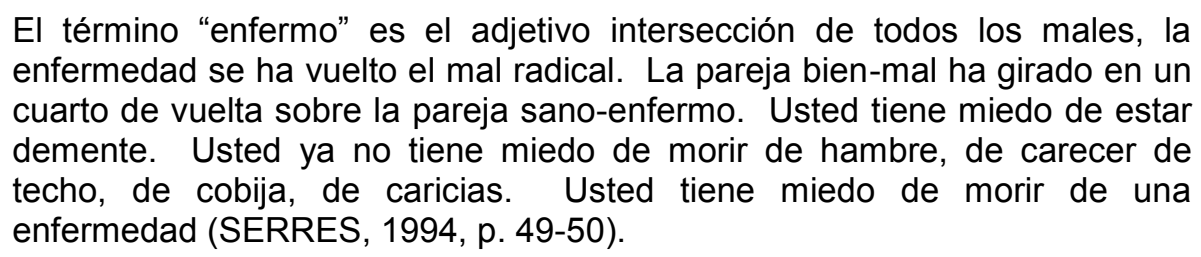

Hoy es apreciable que la supuesta muerte de Dios, preconizada por Nietzsche, no es cierta, pues el nihilismo, el culto a lo fútil, la pasión por la nada, la fascinación por los abismos y agujeros sin fondo donde se pierde el cuerpo, el alma, la identidad se inscriben en un universo de podredumbre que se soporta en la ficción creyente de la ingenuidad consumista. El mundo deviene fábula y la fábula engendra el placebo de la ficción cotidiana. 


\section{REFERENCIAS}

CIORAN, E. Breviario de podredumbre. París: Gallimard, 1949. Tomado de: <http://www.sociologia.org/olddir/text/cioran4.htm>. Visitado en: 30 oct. 2011.

DE GREIFF, L. Selección de poemas. Bogotá: Instituto Colombiano de Cultura, 1972.

DELEUZE, G. Nietzsche y la Filosofía. Barcelona: Anagrama, 1971.

DUMEZIL, G. Del mito a la historia. En: Historia y diversidad de las culturas.

Barcelona: Ediciones del Serbal, Unesco, 1984.

ESPOSITO, R. Bíos. Biopolítica y filosofía. Buenos Aires: Amorrortu, 2006.

HEIDEGGER, M. El origen de la obra de arte. En: Caminos del bosque. Madri: Alianza, 1996.

FOUCAULT, M. La arqueología del saber. México: Siglo XXI, 2010.

GARAVITO, E. Serres y Nietzsche: La Transubstancia de la cultura. En: Revista Ciencias Humanas, n. 19, Universidad Nacional, Medellín. 1993.

GEERTZ, C. La religión como sistema cultural. En: La interpretación de las culturas. México: Gedisa, 1987.

GOUTEUX, J-P. Apología de la blasfemia. En peligro de creer. Madri: Montesinos, 2006.

LAWRENCE, D. H. La serpiente emplumada. Barcelona: Bruguera, 1980.

MANN, Th. La Montaña Mágica. Madri: Plaza \& Janés, 1998.

MANN, M. El lado oscuro de la democracia. Un estudio sobre la limpieza étnica. Valência: Universitat de Valencia, 2009. 
NIETZCHE, F. El Anticristo. En: Obras Completas. v. IV. Madri: Aguilar, 1967.

NIETZCHE, F. El Anticristo. Ecce Homo. Madrid: Alianza, 2005.

ONFRAY, M. Tratad de ateología. Barcelona: Anagrama, 2006.

SARAMAGO, J. El "factor Dios", 2011. Tomado en:

$<$ http://inmaculadadecepcion.blogspot.com/2004/11/jos-saramago-el-factor-

dios 20.html . Visitado en: 25 oct. 2011.

SERRES, M. El Anticristo: Una química de las sensaciones y de las ideas. En: Revista UNAULA, n. 14, Medellín. 1994.

SERRES, M. Desapego, Apólogo. Paris: Flammarion, 1983. Traducción de Luis Alfonso Palau, Universidad Nacional de Colombia, Medellín, 1999.

SERRES, M. Los cinco sentidos. Filosofía de los cuerpos mezclados. México: Taurus, 2002.

SERRES, M. Traición: La thanatocracia. 1974 En: Hermes III: La traducción. Paris: Minuit. Traducción de Luis Alfonso Palau, Medellín, 2006.

ZOLA, É. Nana. Bogotá: Oveja Negra, 1982.

Artigo:

Recebido em: 18/01/2013

Aceito em: 19/07/2013 